\title{
PROSEDUR KREDIT GADAI SYARIAH PADA PT. PEGADAIAN SYARIAH KOTA MAKASSAR
}

\author{
Etik Prihatin $^{1^{*}}$, Muh. Alam Nasyrah Hanafi ${ }^{2 * *}$ \\ ${ }^{1}$ Fakultas Ekonomi dan Bisnis Universitas Universitas Muslim Indonesia \\ ${ }^{2}$ Fakultas Ekonomi dan Bisnis Universitas Muslim Maros \\ *etik.prihatin@umi.ac.id \\ **alamnasyrah@umma.ac.id
}

\begin{abstract}
ABSTRAK
Tujuan penelitian ini adalah Mengetahui, menguraikan dan menerangkan pelaksanaan Prosedur Pemberian Kredit di Perum PT. Pegadaian Cabang Syariah Makassar. Perhitungan Penaksiran Barang Gadai di Cabang PT. Pegadaian Syariah Makassar barang gadai ditaksir atas beberapa pertimbangan, seperti jenis barang, nilai barang dan usia barang.

PT. Pegadaian Syariah Makassar sebagai solusi kredit dengan agunan bunga rendah dibanding pegadaian konvensional, bagi masalah keuangan dan juga masalah finansial yang dihadapi masyarakat tanpa menjual barang berharga.
\end{abstract}

Kata Kunci: Kredit Gadai Syariah

\section{PENDAHULUAN}

\section{A. Latar Belakang}

Diera modernisasi dan kemajuan teknologi seperti saat ini, masyarakat dituntut untuk selalu berkembang dan mengikuti jaman, mulai dari kegiatan sehari-hari hingga pada kegiatan yang bersifat formal. Dalam modernisasi serta kemajuan tersebut, tidak terlepas dari kebutuhan akan uang untuk membeli dan membayar berbagai keperluan yang kian meningkat dengan macam, harga, dan kegunaan yang bervariasi sesuai keperluan. Namun terkadang kebutuhan yang ingin dibeli tidak dapat tercukupi dengan uang yang dimiliki.

Jika sudah demikian kita harus pandai-pandai mengatur pengeluaran dengan mengutamakan membeli keperluan yang sangat penting, namun apabila uang yang dimiliki belum dapat mencukupi, terpaksa harus menunda atau bahkan memupuskan keinginan kita tersebut karena keterbatasan biaya. Namun apabila memang sangat diperlukan dapat kita dapatkan dana

dengan mencari pinjaman dari berbagai sumber dana yang ada.

Apabila dana yang kita butuhkan jumlahnya besar dan dalam jangka pendek relatif sulit, itupun hanya dapat dilakukan di bank dengan berbagai persyaratan yang rumit, serta memakan waktu yang lama karena perlu diadakan analisis yang mendalam oleh bagian kredit di bank tersebut. Namun jika dana yang dibutuhkan relatif kecil tidak begitu sulit untuk mendapatkan pinjaman, banyak tersedia sumber dana yang murah dan cepat disekitar kita, mulai dari meminjam ke tetangga, tukang ijon, atau meminjam pada lembaga keuangan lainnya.

Bagi mereka yang membutuhkan dana dan memiliki barang-barang berharga bisa langsung menjual barangbarang berharga tersebut untuk mendapatkan dana yang diinginkan. Namun resikonya barang-barang berharga kita akan hilang dan sulit untuk kembali. Selain itu, jumlah uang yang 


\section{PAY Jurnal Keuangan dan Perbankan. Vol. 3 No. 1, Juni 2021}

kita peroleh terkadang lebih besar dari yang kita inginkan, sehingga melebihi target dan cenderung pada pemborosan.

Untuk mengatasi masalah tersebut, dimana kebutuhan akan dana dapat dipenuhi tanpa harus kehilangan barangbarang berharga, maka masyarakat dapat menjaminkan barang-barangnya pada lembaga tertentu. Barang yang dijaminkan tersebut, suatu saat dapat ditebus kembali setelah uang pinjamannya dilunasi. "Kegiatan menjaminkan barang-barang berharga untuk memperoleh sejumlah uang dan dapat ditebus kembali setelah jangka waktu tertentu tersebut, disebut juga dengan usaha gadai. Menurut kitab Undang-undang Hukum Perdata Pasal 1150, gadai adalah hak yang diperoleh seorang yang mempunyai piutang atas suatu barang bergerak. (Bank dan Lembaga Keuangan Lain, 2006:212). Barang bergerak adalah barang-barang yang dianggap berharga dan memiliki nilai ekonomi tertentu serta dapat dipindah tangankan, misalnya perhiasan emas, batu mulia, peralatan elektronik, kendaraan, dll.

Dengan usaha gadai tersebut, masyarakat tidak perlu takut kehilangan barang-barang berharga mereka. "Pegadaian adalah satu-satunya BUMN yang secara resmi mempunyai ijin untuk melaksanakan kegiatan Lembaga Keuangan berupa pembiayaan dalam bentuk penyaluran dana ke masyarakat atas dasar hukum gadai seperti dimaksud dalam kitab Undang-Undang Hukum Perdata pasal 1550". ( Bank dan Lembaga Keuangan Lain, 2006:212).

Masyarakat yang ingin menggadaikan barang-barang berharganya, tinggal datang dengan membawa barang-barang tersebut serta membawa identitas diri seperti KTP. Diloket penaksir barang-barang tersebut barang akan di nilai dan petugas akan menawarkan beberapa nilai gadai dari barang tersebut, berupa nilai minimum dan nilai maksimum.

Nilai gadai adalah nilai yang menggambarkan besarnya batas jumlah pinjaman yang diperoleh dengan menggunakan barang yang bersangkutan" (Bank dan Lembaga Keuangan Lain, 2006:211). Setelah mendapatkan persetujuan Kepala Kantor Cabang dan terjadi kesepakatan maka kredit dapat dicairkan.

Bila penggadai tidak dapat menebus kembali barang jaminan mereka, pegadaian dengan sepengetahuan pemilik barang akan melelang barangbarang tersebut. Lelang adalah proses penjualan barang, dimana barang yang bersangkutan akan dijual kepada penawar yang berani membeli dengan harga tertinggi."Proses lelang dilakukan untuk mendapatkan dana guna melunasi seluruh kewajiban nasabah kepada Perum Pegadaian, yang terdiri dari pokok pinjaman, sewa modal (bunga), biaya lelang. Apabila dalam proses lelang terjadi kelebihan dana dari jumlah yang dibutuhkan untuk melunasi pinjaman, maka kelebihan dana tersebut akan dikembalikan kepada penggadai yang bersangkutan dengan batas pengambilan selama 1 tahun".(Credit Manajement Handbook 2006:211).

Dalam realisasinya di Perum PT. Pegadaian Cabang syariah Makassar prosedur pemberian kredit telah sesuai dengan prosedur yang ada, mulai dari persyaratan, pelaksanaan hingga pada pelunasan dan pelelangan barang jaminan, karena hal ini berkaitan dengan pelayanan pinjaman, dokumentasi dan pengelolaan data administratif perusahaan, pengelolaan barang jaminan, serta pengawasan kredit, dalam kaitannya dengan profit dan visi misi perusahaan.

Dengan demikian dapat disimpulkan, bahwa Pegadaian adalah satu-satunya $\quad$ BUMN yang secara 


\section{PAY Jurnal Keuangan dan Perbankan. Vol. 3 No. 1, Juni 2021}

resmi mempunyai ijin untuk melaksanakan kegiatan Lembaga Keuangan berupa pembiayaan dalam bentuk penyaluran dana ke masyarakat atas dasar hukum gadai kepada masyarakat luas terutama kalangan menengah kebawah dengan prosedur yang mudah dan sederhana atas dasar hukum gadai dengan menjaminkan barang-barang berharga mereka, seperti perhiasan emas, berlian, kendaraan bermotor, atau BPKB kendaraan bermotor, sesuai standart yang ditentukan. Sesuai dengan slogannya, "Mengatasi Masalah Tanpa Masalah". Masyarakat tidak perlu khawatir jika tidak ingin barang yang dijaminkannya hilang, karena dapat diambil kembali bila pinjaman telah dilunasi. Hal tersebut adalah kelebihan dari Perum Pegadaian, juga hal yang membuatnya khas dan berbeda dengan lembaga keuangan lainnya.

\section{B. Rumusan Masalah}

Berdasarkan latar belakang masalah yang telah dikemukakan, maka penulis merumuskan masalah adalah bagaimana prosedur pemberian kredit pada PT. Pegadaian Syariah Makassar?

\section{Tujuan Penelitian}

Mengetahui, menguraikan dan menerangkan pelaksanaan Prosedur Pemberian Kredit di PT. Pegadaian Cabang syariah Makassar.

\section{TINJAUAN PUSTAKA}

\section{A. Pengertian Kredit}

Arti Kredit dalam UU No.7 Tahun 1992 (UU Perbankan) adalah "Penyediaan uang atau tagihan yang disamakan dengan itu berdasarkan persetujuan atau kesepakatan antara bank dengan pihak lain yang mewajibkan pihak peminjam melunasi utangnya setelah jangka waktu tertentu dengan jumlah imbalan atau pembagian hasil keuntungan".

\section{B. Tujuan Kredit}

Unsur safety dan unsur profitability yang saling berkaitan dengan tujuan kredit (Credit Manajemen Handbook $2006: 6-7)$ :

1. Safety atau keamanan yaitu prestasi yang diberikan dalam bentuk uang, barang, atau jasa, itu betul-betul terjamin pengembaliannya, sehingga keuntungan/profitability yang diharapkan dapat terwujud.

2. Profitability atau keuntungan merupakan tujuan utama dari pemberian kredit berupa bunga yang diterima.

\section{METODE ANALISIS}

Dalam pengamatan ini penulis menggunakan teknik analisis data kualitatif yaitu pengambilan data yang bersifat khusus yang ada kaitannya dengan permasalahan yang diamati.

Teknik analisis data kualitatif sebagai cara penjabaran terhadap datadata yang telah diperolah berdasarkan study litterateur yang telah diperoleh tersebut disusun dalam bentuk pengumpulan data, sajian data dan selanjutnya diambil kesimpulan yang kesemuanya saling berkaitan dengan proses pengumpulan data.

\section{HASIL PENELITIAN}

\section{A. Prosedur Kredit Gadai}

Adapun prosedur kredit gadai syariah dari hasil pengamatan yang di dapatkan dari PT. Pegadaian Syariah Makassar adalah :

1. Besar kredit yang diberikan sama dengan Gadai Konvensional/ KCA, namun berbeda dalam proses penetapan sewa modal. Gadai syariah menerapkan biaya administrasi dibayar dimuka, yaitu 


\section{PAY Jurnal Keuangan dan Perbankan. Vol. 3 No. 1, Juni 2021}

saat akad baru/ akad perpanjangan serendah-rendahnya $\mathrm{Rp} 1.000$ dan setinggi-tingginya $\mathrm{Rp} 60.000$ untuk jumlah pinjaman maksimum $\mathrm{Rp}$ 200.000.000. Tarif Ijarah dekenakan sebesar Rp 15 - Rp 85 per sepuluh hari masa penyimpanan untuk setiap kelipatan Rp 10.000 dari taksiran barang jaminan yang dititipkan/ diagunkan.

2. Persyaratan :
a. Fotocopy KTP atau identitas resmi lainnya.
b. Menyerahkan barang jaminan.
c. Untuk kendaraan bermotor membawa BPKB dan STNK asli.

\section{B. Pembahasan Prosedur Kredit Gadai Syariah}

Prosedur Pengajuan Pinjaman di cabang PT.Pegadaian Syariah Makassar adalah sebagai berikut :

1. Rahin (nasabah) mendatangi kantor pegadaian syariah dan langsung menuju loket atau meja penaksir untuk meminta fasilitas pembiayaan dengan membawa marhun (barang jaminan) yang akan diserahkan kepada murtahin dan membawa fotocopy KTP atau SIM.

2. Penaksir melakukan pemeriksaan barang dan menaksir barang jaminan tersebut.

3. Setelah persyaratan terpenuhi maka murtahin dan Rahin melakukan akad rahn dan kemudian melakasanakan akad ijarah (untuk menyewa tempat bagi marhun).

4. Setelah akad dilakukan, maka kasir akan memberikan sejumlah pinjaman uang yang jumlahnya dibawah nilai marhun yang telah ditaksir oleh murtahin, yaitu sekitar 92\% dari harga taksiran marhun.

5. Rahin dapat melunasi marhun menurut akad : yaitu pelunasan penuh, ulang rahn, atau tarif ijarah selama jangka waktu tersebut.

6. Perhitungan Penaksiran Barang Gadai di Cabang PT. Pegadaian Syariah Makassar Barang gadai di taksir atas beberapa pertimbangan, seperti jenis barang, nilai barang, usia barang dsb.

\section{Perhitungan Penaksiran Barang Gadai di Cabang Pegadaian Syariah}

1. Prosedur Penaksiran Emas

Standar penaksiran yang digunakan oleh Pegadaian adalah 92\% x harga pasaran emas. Misalkan, harga pasaran emas adalah Rp. 740.000 maka perhitungan emas dapat di ilustrasikan dalam tabel sbb :

Tabel 5.1 Perhitungan Emas

$\begin{array}{cccc}\text { No } & \begin{array}{c}\text { Jumlah } \\ \text { Karat }\end{array} & \begin{array}{c}\text { Perhitungan } \\ \text { Taksiran }\end{array} \\ 1 & 24 & 92 \% \text { xp. } 740.000 & \text { Rp. } 680.800 \\ 2 & 23 & 23 / 24 \times \text { Rp. } 740.000 \times 92 \% & \text { Rp. } 652.433 \\ 3 & 22 & 22 / 24 \times \text { Rp. } 740.000 \times 92 \% & \text { Rp. } 624.066 \\ 4 & 21 & 21 / 24 \times \text { Rp. } 740.000 \times 92 \% & \text { Rp. } 595.700\end{array}$

Contoh :

Salman menggadaikan gelang emas.

Setelah ditaksir petugas ternyata gelang tersebut 24 karat dengan berat 5 gram dengan harga pasaran emas Rp. 740.000. Berapakah nilai taksiran gelang tersebut?

Jawab :

5 gram $x$ Rp. $680.800=$ Rp. 3.404 .000

2. Prosedur Penaksiran Barang Elektronik

Dilakukan dengan cara melihat harga di pasar, Pegadaian harus menentukan prosentase terhadap barang tersebut. Penaksiran dilakukan dengan cara mengkalikan $65 \%$ dengan harga setempat dan dikalikan dengan harga standar penaksiran yaitu $92 \%$.

Contoh :

Aril berniat menggadaikan laptopnya di pegadaian syariah dan ditaksir dengan harga setempat Rp. 3.000.000. Berapa nilai taksiran laptop tersebut? 


\section{PAY Jurnal Keuangan dan Perbankan. Vol. 3 No. 1, Juni 2021}

Jawab :

Rp. $3.000 .000 \times 65 \%=$ Rp. $1.950 .000 \times 92 \%$ $=$ Rp. 1.794 .000

Jadi Dhimas akan mendapatkan pinjaman sebesar Rp. 1.794.000

3. Prosedur Penaksiran Kendaraan Bermotor

Didasarkan pada harga barang setempat, setelah diketahui harga pasarannya kemudian dikalikan $75 \%$ dan dikalikan dengan standar penaksiran pegadaian yaitu $92 \%$.

Contoh :

Bapak Sugito ingin menggadaikan Sepeda Motornya yaitu Honda Beat tahun 2011, dengan harga pasaran setempat Rp. 10.000.000. Berapa uang pinjaman yang akan diterimanya?

Jawab :

Rp. $10.000 .000 \times 75 \%=$ Rp. $7.500 .000 \times 92 \%$ $=$ Rp. 6.900 .000

Jadi Bapak Sugito akan mendapatkan uang pinjaman sebesar Rp. 6.900 .000

\section{Perhitungan Biaya Ijarah di Pegadaian Syariah}

Biaya sewa yang biasa di Pegadaian Syariah disebut dengan ijarah yaitu, biaya sewa tempat yang dikenakan oleh pihak Pegadaian atas barang yang digadaikan nasabah. Biaya ijarah dapat dihitung setelah barang yang digadaikan ditaksir oleh pihak pegadaian

Tabel 5.2 Perhitungan Biaya Ijarah

$\begin{array}{ccc}\text { No } & \text { Jenis Marhun } & \text { Perhitungan Tarif } \\ 1 & \text { Emas } & \text { Taksiran/Rp. 10.000 x Tarif } \\ & & \text { x } \\ & & \text { Jangka Waktu/10 Hari } \\ 2 & \text { Elektronik dan } & \text { Taksiran/Rp. 10.000 x Tarif } \\ & \text { Alat Rumah } & \text { x } \\ & \text { Tangga Lainnya } & \text { Jangka Waktu/10 Hari } \\ 3 & \text { Kendaraan } & \text { Taksiran/Rp. 10.000 x Tarif } \\ & \text { Bermotor (Mobil } & \text { x } \\ & \text { dan Motor) } & \text { Jangka Waktu/10 Hari }\end{array}$

Keterangan :

Taksiran = Harga $/$ nilai suatu barang. Tarif = Rp. 45, Rp. 71, Rp. 71, Rp. 62 adalah ketetapan tarif pegadaian syariah $\mathrm{K}=$ Konstanta ditetapkan Rp. 10.000
Jangka Waktu = Waktu pinjaman barang yang digadaikan dihitung persepuluh hari.

Dari rumus tersebut, jelas bahwa pihak pegadaian menetapkan biaya ijarah bukan dari jumlah pinjaman nasabah, karena yang dihitung adalah besarnya nilai harga taksiran, angka $\mathrm{Rp}$. 10.000 adalah angka konstanta yang digunakan pihak pegadaian dalam menghitung ijarah, sedangkan tarif angka Rp. 45, Rp. 71, Rp. 71, dan Rp. 62 adalah penentuan tarif standar yang digunakan pegadaian syariah.

Ketentuan-ketentuan tarif ijarah sebagai pembentuk laba perusahaan sebagai berikut:

1. Tarif jasa simpan dihitung dari nilai taksiran barang/marhun bih.

2. Jangka waktu gadai ditetapkan 120 hari kalender. Perhitungan tarif jasa simpan dengan kelipatan sepuluh hari dihitung sejak pinjaman rahn sampai dengan tanggal melunasi pinjaman, satu hari dihitung sepuluh.

3. Tarif dihitung berdasarkan volume atau nilai barang.

4. Rahin dapat melunasi sebelum jatuh tempo.

5. Tarif jasa simpan dan pemeliharaan (biaya ijarah) dibayar pada saat melunasi pinjaman.

\section{KESIMPULAN}

Berdasarkan hasil penelitian maka dapat disimpulkan oleh peneliti terkait prosedur kredit rahn (gadai syariah) adalah :

1. Rahn adalah menyalurkan Marhun Bih dalam jumlah skala kecil dengan jaminan harta bergerak maupun tidak bergerak atas dasar hukum Gadai Islam.

2. Perhitungan Penaksiran Barang Gadai di Cabang PT. Pegadaian Syariah Makassar barang gadai ditaksir atas beberapa pertimbangan, 


\section{PAY Jurnal Keuangan dan Perbankan. Vol. 3 No. 1, Juni 2021}

seperti jenis barang, nilai barang dan usia barang.

3. PT. Pegadaian Syariah Makassar sebagai solusi kredit dengan agunan bunga rendah dibanding pegadaian konvensional, bagi masalah keuangan dan juga masalah finansial yang dihadapi masyarakat tanpa menjual barang berharga.

\section{SARAN}

Dari hasil penelitian adapun saran dari penulis yaitu diharapkan lebih mensosialisasikan produk-produk penggadaian dan keberadaannya kepada masyarakat yang lebih luas, sehingga penggadaian syariah Makassar bisa diketahuai masyarakat luas dan dijadikan sebagai lembaga keuangan alternatif.

\section{DAFTAR PUSTAKA}

Abdul Aziz Dahlan, Ensiklopedi Hukum Islam, Jakarta: Ichtiar Baru Van Hoeve, 2000. hlm. 10.

Ahmad kamil, Kitab undang-undang hukum perbankan dan syariah (Jakarta:kencana,2007) hal.545-559.

Hanafi, M.A.N. \& Shofiana Syam. 2019. Analisis Kinerja Keuangan berdasarkan Prinsip CAMEL pada PT. Bank Rakyat Indonesia (BRI) yang Terdaftar di Bursa Efek Indonesia. PAY Jurnal Keuangan dan Perbankan, Vol.1 No.1,48-57.

https://ejournals.umma.ac.id/ind ex.php/pay/article/view/216

Ma'ruf Amin, Mengatasi Masalah Dengan Pegadaian Syariah (Jakarta: Renaisan, 2005), hal.49.

Nasrun Haroen, Fiqh Mu'amalah, Jakarta: Gaya Media Pratama, 2000, cet. ke-1, hlm. 251.

Nasrun Haroen, Fiqh Mu'amalah, Jakarta: Gaya Media Pratama, 2001.
Kasmir, Bank dan Lembaga Keuangan

Lainnya, (Jakarta: PT Rajagrafindo, 2008) Hlm. 266

Khaerul Umam, (2013), Manajemen Perbankan Syariah, Bandung: CV Pustaka Setia.

Pirgon matua, sejarah singkat perusahaan umum (perum) pegadaian (Jakarta:2003), hal 1.

Sri Nurhayati dan Wasilah, (2009), Akuntansi Syariah di Indonesia, Jakarta: Salemba Empat.

HB Sutopo, (2002), Metodologi Penelitian Kualitatif, Surakarta:UNS Press.

Websait pegadaian.co.id/info-visimisi.php Pada Tanggal, 12 juli 2019. 